\title{
Solec Spa - worldwide unique properties of Polish health resort in the service of rural medicine
}

\author{
Marek L Grabowski ${ }^{1,2}$, Bożena Kosińska ${ }^{3}$, Józef P Knap ${ }^{4}$ \\ ${ }^{1}$ Institute of Natural Medicine in Solec Zdrój, Poland \\ 2 Department of Nursing, University of Management, Częstochowa, Poland \\ ${ }^{3}$ The Independent Regional Public Psychiatric Hospital, Radom, Poland \\ ${ }^{4}$ Department of Epidemiology, Warsaw Medical University, Poland
}

Grabowski ML, Kosińska B, Knap JP. Solec Spa - worldwide unique properties of Polish health resort in the service of rural medicine. Ann Agric Environ Med. 2018; 25(1): 46-49. doi: 10.5604/12321966.1228402

\section{Abstract}

Solec Spa is health resort in south-eastern Poland. Its unique balneorehabilitation significance worldwide is determined by chloride-iodine-sodium water with a high content of hydrogen sulphide. This water, classified as highly mineralized sodiumchloride (seltzer) sulphide, bromide, iodide, boron water, contains naturally approximately $0.9 \mathrm{~g} / \mathrm{l}$ divalent sulphur compounds, which is the highest concentration noted among the mineral waters of the world. The effectiveness of the Solec waters is proven in: inflammatory and autoimmunological locomotor system diseases, degenerative joint disorders (osteoarthritis), post-traumatic and post-operative orthopedic diseases, skin diseases and allergic disorders. One of the main indications for balneotherapy in Solec Spa and Busko Spa is chronic brucellosis.

\section{Key words}

Solec Spa, balneotherapy, sulfuric-salty, rural medicine, highly mineralized sulfide water, chronic brucellosis

\section{INTRODUCTION}

Solec Spa is a small but rapidly growing health resort in south-eastern Poland (Map 1), on the Małopolska Upland, in the mesoregion of the Solecka Basin. It is located in one of the environmentally cleanest places in Poland, surrounded by forest, with a rich tree stand of spa park and a water reservoir on the river [1,2], it is also in the area of the early medieval splendour of Poland (near Wiślica) [3, 4]. Physiographic characteristics of Solec Spa is represented in the following way by one of the most outstanding Polish experts in geography, Professor Jerzy Kondracki (1908-1998): 'On the

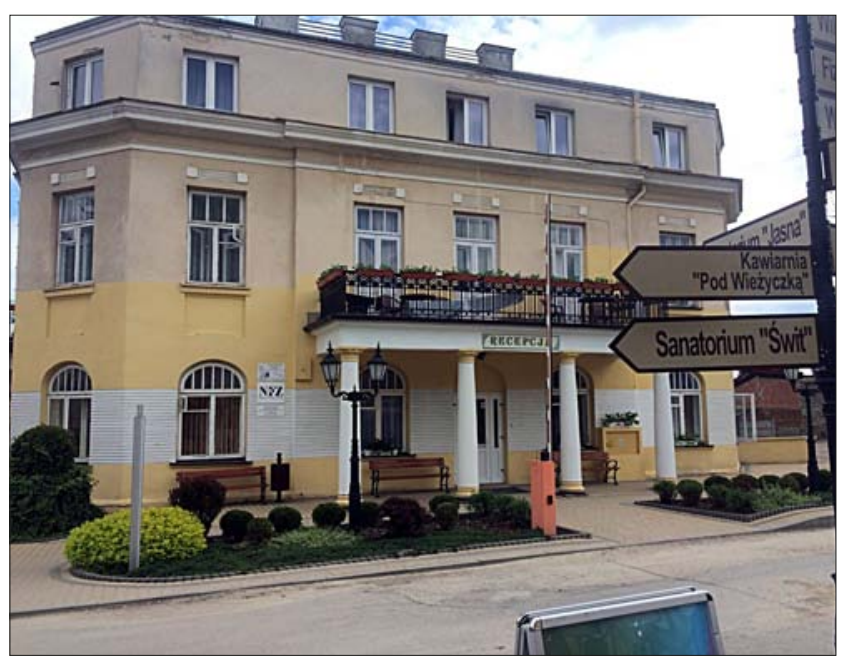

Figure 1. Sanatorium 'Jasna'

Address for correspondence: Bożena Kosińska, The Independent Regional Public Psychiatric Hospital, Radom, Poland

E-mail: bozko@vp.pl

Received: 15 May 2016; accepted: 7 June 2016; first published on December, 2016
Cretaceous Marl lightly folded sediments of mudstone sea are resting, represented by Lithothamnium limestone and gypsum (Torton) (...). Sources of sulfur are associated with the presence of gypsum, which gave rise to the spas in Busko and Solec' [5]. Their unique balneorehabilitation significance worldwide is determined by chloride-iodine-sodium waters with a high content of hydrogen sulphide $\left(\mathrm{Cl}-\mathrm{Na}+\mathrm{J}+\mathrm{H}_{2} \mathrm{~S}\right)$ $[6,7,8,9,10]$.

Drilling in search of seltzers was carried out in 1824 by a team led by Ernest Becker from Saxony. At a depth of $145 \mathrm{~m}$, sulfuric-bitter-salty waters were obtained, on which physico-chemical analysis was conducted in 1840 by Adam Maximilian Kitajewski, the Professor of Chemistry at the University of Warsaw, who described them as 'sulfuric-salty alkaline waters'. The efficiency of this so-called 'old spa' was $45 \mathrm{cu} \mathrm{m}$ of water with a specific gravity of 1.015063 , temperature 12.4 degrees Celsius, and with an alkaline reaction.

The great European and Polish internist, Professor Józef Dietl (1804-1878), a postgraduate of medicine in Vienna and Rector of the Jagiellonian University in Krakow, from 1855 studied the Solec waters and summed up their values:

The Solec spring is one of the strongest and most effective of its kind in Europe (...). In all severe and persistent cases Solec proved the effectiveness, in this respect we can do without any other foreign spa, and even boldly renounce without hesitation, what Solec is not able to achieve, that the more no other spring is able to achieve.

\section{Original Old Polish text:}

Źródło soleckie należy do najsilniejszych i najskuteczniejszych tego typu w Europie. (...). We wszystkich ciężkich i uporczywych wypadkach dowiódł 
Solec takiej skuteczności, iż pod tym względem możemy się obejść bez każdego innego zagranicznego zdroju, a nawet śmiało wyrzec nie wahamy się, iż czego Solec nie jest w stanie dokazać, tego tym bardziej nie dokaże inne źródło [11].

These words published in 1858 are all the more important because the great clinician, sceptical in evaluating the therapeutic possibilities of nineteenth century medicine, wrote them not only as a physician-scientist, a pioneer in balneology in Poland, but also as a patient suffering from rheumatoid arthritis, who greatly benefited from these waters.

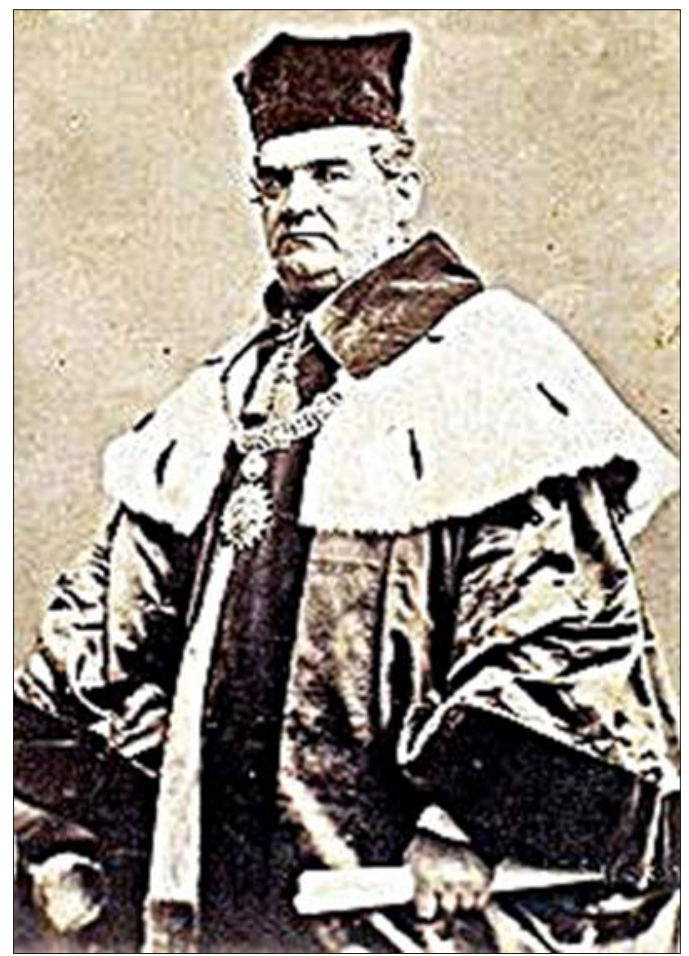

Figure 2. Józef Dietl

In reborn Poland, Associate Professor Kirkor of the National Institute of Food Research and Consumer Articles, conducted tests twice, in 1925 and 1933, on the therapeutic materials of Solec. In 1936, the Solec spa physician, Dr. Jan Anyszek, published in the professional journal 'Solecka water and its therapeutic importance' both test results of Kirkor, together with a comparative statement by Professor Ludomir Korczyński (1867-1936), a leading Polish balneologist, In the National Institute of Food Research and Consumer Articles chemical composition of the Solec 'sulfur salines' was determined as follows (in grams per 11 ):

- hydrogen sulphide - 0.103

- solids - 20.544

- sodium chloride - 15.281

- calcium sulfate - 1.965

- magnesium sulfate - 1.939

- potassium chloride -0.112

- ammonium chloride - 0.030

- lithium chloride - 0.00762

- natrium iodine -0.0017

- natrium bromide -0.0011 .
On the other hand, Korczyński ranked the Polish and foreign sulfur salines spas in terms of the content of hydrogen sulphide in 11 of water [12]. A list of 25 spas in Europe, Asia and Africa, are quoted, regarding the water with the highest content of $\mathrm{H}_{2} \mathrm{~S}$ (in grams per $1 \mathrm{l}$ ):

- Mazesta (Caucasus) - 0.28

- Rops (Hungary) - 0.273

- Niemirów (Alexandra spa, potable water) - 0.148

- Lubień Wielki - 0.111

- Solec - 0.103

- Heluan (Egypt) - 0.073

- Swoszowice - 0.064

It should be added that in the neighbouring Busko spa, thehydrogen sulphide content was 10 times smaller $(0.013 \mathrm{~g} / \mathrm{l})$ [13]. Anyszek commented as follows on the Table:

Therefore, Solec, in terms of the content of hydrogen sulphide, yields only to the two Polish springs (in the then Second Republic - ed. authors) of the sulphate-calcium group. In the group of sulfate-seltzer it has a prominent place in terms of hydrogen sulphide, and the content of solids per litre'.

Research in the second half of the twentieth century revealed even more unique therapeutic waters at Solec. In 1966, the drilling of Solec-II was carried out and named the 'Charles' spa in honour of Charles Geodfrey [14, 15] (Fig. 3). Chloride-sulphate-sodium, bromide, iodide, boron sulphide with the content of hydrogen sulphide $-0.07 \mathrm{~g} / \mathrm{l}$ water was obtained. Table 1 shows the chemical composition and other features of the intakes of mineral water (Tab. 1). Figure 3 shows their location at the resort.

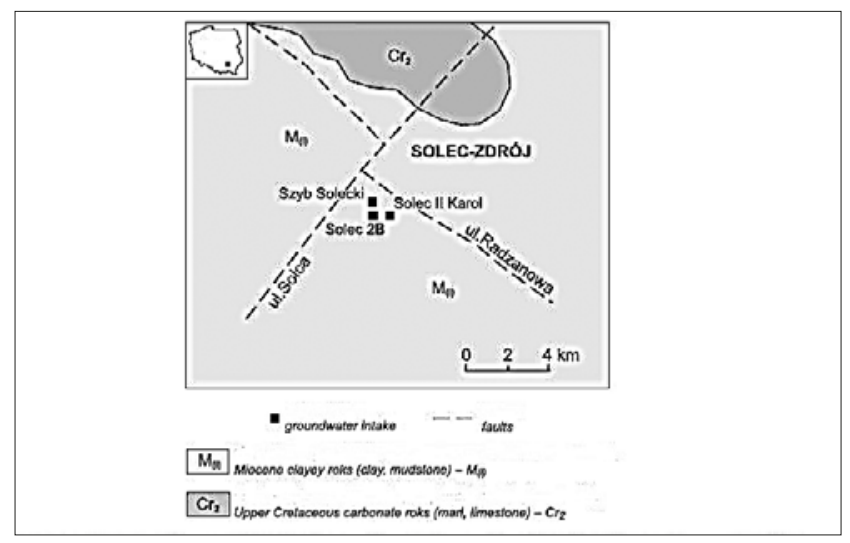

Figure 3. Location of groundwater intakes of mineral waters against the elements of geological structure in the Solec Spa region (according to Herman, Gągol) [16]

Table 1. Chemical composition of therapeutic water of Solec Spa (own study based on I. Lipiec and I. Lipiec and B. Wiktorowicz, 2015) [17]

\begin{tabular}{|c|c|c|c|c|c|}
\hline $\begin{array}{l}\text { Intake } \\
\text { name }\end{array}$ & $\begin{array}{c}\text { Depth [m] } \\
\text { stratigraphy }\end{array}$ & Efficiency & $\begin{array}{l}\text { Chemical } \\
\text { type }\end{array}$ & $\begin{array}{c}\text { Total Dissolved } \\
\text { Solids (TDS) } \\
{[\mathrm{g} / \mathrm{l}]}\end{array}$ & $\begin{array}{c}\text { Sulphur (II) } \\
{[\mathrm{g} / \mathrm{l}]}\end{array}$ \\
\hline $\begin{array}{l}\text { Solec } \\
\text { Shaft }\end{array}$ & $\begin{array}{c}170.0 \\
\text { Jurassic / Middle } \\
\text { Cretaceous }\end{array}$ & 0.45 & $\begin{array}{c}\mathrm{Cl}-\mathrm{Na}-\mathrm{SO}_{4} \\
\mathrm{~S}, \mathrm{I}, \mathrm{F}\end{array}$ & 18.4 & 0.1528 \\
\hline Solec 2B & $\begin{array}{c}121.0 \\
\text { Upper } \\
\text { Cretaceous }\end{array}$ & 0.51 & $\begin{array}{c}\mathrm{Cl}-\mathrm{Na}-\mathrm{SO}_{4} \\
\mathrm{~S}, \mathrm{I},\end{array}$ & 16.5 & 0.201 \\
\hline $\begin{array}{l}\text { Solec II } \\
\text { Charles }\end{array}$ & $\begin{array}{c}121.6 \\
\text { Upper } \\
\text { Cretaceous }\end{array}$ & 0.15 & $\begin{array}{l}\mathrm{Cl}-\mathrm{Na} \\
\mathrm{S}, \mathrm{I}, \mathrm{F}\end{array}$ & 20.6 & 0.0413 \\
\hline
\end{tabular}


In the 1970s, the 'Malina' was discovered in the Jurassic limestone and its exploitation started in 2004.

This water, classified as highly mineralized sodium-chloride (seltzer) sulfide, bromide, iodide, boron water, contains naturally approximately $0.9 \mathrm{~g} / \mathrm{l}$ divalent sulfur compounds, which is the highest concentration noted among mineral waters worldwide. The unique global dimension of Solec sulfate seltzer concerns not only the very high concentration of sulphide ions of $0.103 \mathrm{~g} / \mathrm{l}$, but also the high mineralization. The powerful effect of sulphate-hydrogen sulphide waters, release of divalent ions of sulfur and thiol groups $(\mathrm{SH}=$ hydrogen sulphide) deeply penetrate the skin, contribute to wide use, so enthusiastically emphasized already by the clinician Professor. Dietl. The effectiveness of the Solec waters has been proved in:

- inflammatory and autoimmunologically conditioned diseases of the locomotor system, such as rheumatoid arthritis, psoriatic arthritis, ankylosing spondylitis, chronic brucellosis, fibromyalgia;

- degenerative joint disorders (osteoarthritis) and overuse syndrome;

- post-traumatic and post-operative orthopedic diseases of the locomotor system;

- skin diseases of different etiology: psoriasis, scleroderma, seborrheic dermatitis, atopic dermatitis [18, 19];

- allergic disorders of different clinical manifestations and diseases with atopic components.

Unfortunately, there is a discrepancy between the very good knowledge of the physico-chemical properties of the Solec waters, and the number of strictly medical works on their influence and scientifically proven effectiveness, which for a long time has been emphasized by the clinical experience. Much more work concerns the nearby Busko Spa, which has similar therepautic waters, allows for inference by analogy about the indications for balneotherapy in Solec Spa. There is also the clinical experience confirmed by numerous medical studies regarding the effectiveness of the waters and Solec peloids [e.g. 1, 3, 11, 12, 20, 21]. It is also important to remember the world's highest known concentration of divalent sulfur which is very well absorbed by the coating which has been proved by the experiments with the isotopelabeled sulphur - and powerful anti-inflammatory effect.

One of the main indications for balneotherapy in the Solec and Busko Spas is chronic brucellosis. For decades in both spas, patients with occupational brucellosis have been treated (mainly doctors and veterinary technicians, zoo technicians, farmers) with excellent results. The indication for the sanatorium and resort treatment are its chronic symptomatic forms with changes in the locomotory and/ or nervous system, especially the peripheral and vegetative. Chronic degenerative-inflammatory process with the active immunological mechanisms, mainly of delayed hypersensitivity type and the activation of a cascade of pro-inflammatory cytokines and central role of the UPR (Unfolded Protein Response), shapes the very rich clinical picture of chronic brucellosis [20, 21, 22, 23, 24, 25, 26]. The high effectiveness of balneotherapy, with the retreat of the active disease process, is the effect of the spa constituents (mainly divalent sulfur and $\mathrm{SH}$ groups) on both pathogenic components: degenerative and inflammatory. In studies by Beklemiszew etal., as well as the Polish experience, this treatment reduces the symptoms of infectious allergy [20,23].
Equally high efficiency concerned patients with psoriasis and seborrheic dermatitis [19] and chronic (and often neglected and inveterate), degenerative changes or traumatic, so frequent in the population of agriculture. Faced with such consistent, long-term medical experiences, a clinical trial with randomization should definitely be planned.

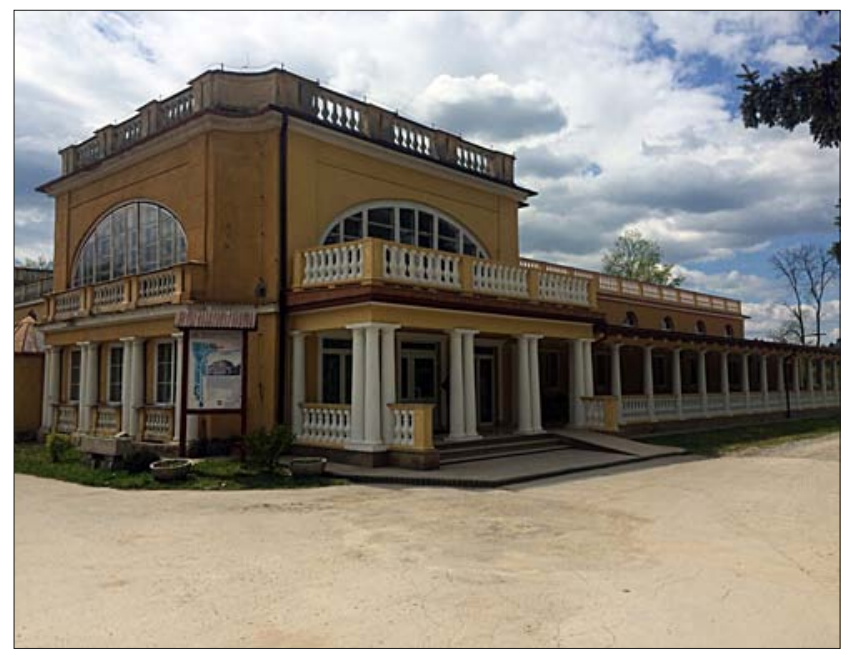

Figure 4. Sanatory baths

A summary of the growing number of patients and procedures performed during the period 1862 - 1928, shows the development and the increasing importance of spas in the nineteenth century and in interwar Poland [27] (Tab. 2), and in years 2010-2015 (Tab. 3). Table 2 shows the number of stationary patients benefiting from the Solec Spa within the National Health Fund; however, patients of the luxurious 'Malinowy Zdrój' private resort are not included. Among patients from National Health Fund, $75-80 \%$ are patients from rural areas or small towns, the great majority from eastern and south-eastern Poland. The patients of 'Malinowy Zdrój'come from all over Poland and from many European countries.

Table 2. Number of patients and treatments in Solec Spa 1862-1928 (according to Smarzyński) [13]

\begin{tabular}{ccc}
\hline Year & No. of bathings & No. of patients \\
\hline 1862 & 10,102 & 367 \\
1872 & 8,686 & 355 \\
1882 & 12,863 & 468 \\
1895 & 15,426 & 554 \\
1913 & 35,000 & 1,400 \\
1923 & 36,500 & 1,460 \\
1924 & 35,500 & 1,420 \\
1925 & 29,500 & 1,180 \\
1926 & 31,500 & 1,240 \\
1927 & 36,500 & 1,460 \\
1928 & 43,000 & 1,720 \\
\hline
\end{tabular}

Table 3. Number of patients and person-days in 2010-2015 (authors' own data)

\begin{tabular}{ccc}
\hline Year & No. of person-days & No. of patients \\
\hline 2010 & 60,561 & 3,834 \\
2011 & 63,979 & 4,048 \\
2012 & 70,818 & 4,521 \\
2013 & 83,147 & 5,074 \\
2014 & 84,429 & 5,154 \\
2015 & 83,103 & 5,268 \\
\hline
\end{tabular}




\section{REFERENCES}

1. Gonda-Soroczyńska E. Przestrzeń uzdrowiskowa w krajobrazie kulturowym wsi na przykładzie uzdrowiska Solec-Zdrój. Infrastructure and Ecology of Rural Areas. 2011; 1: 39-49. (in Polish).

2. Kajoch A. (eds.). Atlas of Polish Health-Resorts. Warszawa - Wrocław, PPWK, 1990. (in Polish).

3. Helis M. (eds.). Solec-Zdrój wczoraj i dziś. Kielce - Solec-Zdrój, SSK Solec-Zdrój, 2008. (in Polish).

4. Szybowska R, Kupiec B. Kościół pw. Świętego Mikołaja w Solcu Zdroju. Kielce, Wydawnictwo „Jedność”, 2013. (in Polish).

5. Kondracki J. Geografia Polski. Mezoregiony fizyczno-geograficzne. Warszawa, PWN, 1994. (in Polish).

6. Daniewski W. Solec, wody alkaliczne, siarczano-słono-wapniowe, zawierające jod, sól gorzką i sól glauberską. Warszawa, 1896. (in Polish)

7. Kaczyński A. O możliwości uzyskania termy siarczano-solankowej w Solcu Zdroju. Acta Balneologica Polonica. 1938; 2: 5. (in Polish).

8. Dzierżyński M. Wody siarczkowo-siarkowodorowe. In: Jankowiak J. (eds.). Balneologia kliniczna. 2nd ed. Warszawa, PZWL, 1971. p. 130-134. (in Polish).

9. Kulikowska J. Przyczyny do poznania genezy wód mineralnych regionu Buska i Solca oraz możliwości zwiększania ich zasobów. Problemy uzdrowiskowe. 1976; 6-8: 191-212. (in Polish).

10. Łajczak A. Źródła mineralne Niecki Nidziańskiej. Czasopismo Geograficzne. 2001; 72(2): 151-184. (in Polish).

11. Dietl J. Źródła lekarskie w Solcu. Kraków, 1858. (in Polish).

12. Anyszek J. Woda solecka i jej znaczenie lecznicze. Przegląd ZdrojowoKąpielowy i Przewodnik Turystyczny. 1936; 3: 21 - 25. (in Polish)

13. Smarzyński H. Powiat Busko Zdrój przed 1.X.1939 r. i w okresie okupacji niemieckiej w latach 1939-1945. Kraków, PWN, 1960. (in Polish).

14. Mazur W. Solec. Część III. Problemy Uzdrowiskowe. 1975; 4(92): 109-117. (in Polish).

15. Lipiec I. Preliminary chemical analysis of stability components and estimation of the trend in the Solec Spa therapeutic water quality changes. Biuletyn Państwowego Instytutu Geologicznego. 2009; 436: 323-328.

16. Herman G, Gągol J. Wody podziemne aglomeracji kieleckiej i Buska Zdroju. [in:] LXXVII Zjazd Naukowy Pol. Tow. Geol., Państw. Inst. Geol., Warszawa. 2006: 205-209. (in Polish).

17. Lipiec I, Wiktorowicz B. Hydrogeochemical characteristic of sulphurous waters from the Solec-Zdrój area. Prz. Geol. 2015; 63: 908-911. (in Polish).

18. Jankowiak J. (eds.). Balneologia kliniczna. 2nd ed. Warszawa, PZWL, 1971. (in Polish).

19. Juszkiewicz-Borowiec M, Chodorowska G, Wojnowska D. Salty mineral sulphide-hydrogen sulphide water from Busko-Solec SPA in the treatment of psoriasis and seborrhoic dermatitis of the scalp. Balneologia Polska. 2005; 3-4: 84-87.

20. Beklemiszev N.D. Chroniczeskij i latentnyj brucellez. Izd. AMN. Ałma Ata. 1965. (in Russian).

21. Beklemiszev N.D. (eds.). Immunoterapija pri alergii k mikrobam. Izd. Nauka. Ałma-Ata.1980. (in Russian).

22. Arct W.A. Ortopedyczne problemy narządu ruchu w brucelozie. Warszawa-Wrocław, PWN, 1972. (in Polish).

23. Dziubek $Z$. The brucellosis infections consequences of the people. Życie Weterynaryjne. 1981; 56 (10-12): 306-308.

24. Kasatkina I.L, Beklemiszev N.D. Patogenez porażenij sustavov pri brucellezie. Izd.AMN. Ałma Ata. 1976. (in Russian).

25. Kassur B, Dziubek Z. Bruceloza (Brucellosis). In: Kassur B. (eds.). Choroby zakaźne i inwazyjne. 2nd ed. Warszawa, PZWL; 1979. p. 166-175. (in Polish).

26. De Figueiredo P, Ficht T.A, Rice-Ficht A, Rosetti C.A, Adams L.G. Pathogenesis and Immunobiology of Brucellosis. Amer. J. Pathol. 2015; 185 (6): 1505-1512.

27. „Solec-Zdrój Zakład Wód Mineralnych Siarczano-Słonych i Kąpieli Mułowych”. Zarząd Zakładu Zdrojowego w Solcu-Zdroju. 1936. (in Polish). 